\title{
Autophagy buffers Ras-induced genotoxic stress enabling malignant transformation in keratinocytes primed by human papillomavirus
}

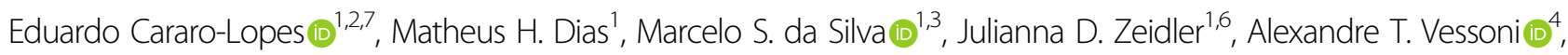
Marcelo S. Reis (1) ', Enrique Boccardo ${ }^{5}$ and Hugo A. Armelin (10),

\begin{abstract}
Malignant transformation involves an orchestrated rearrangement of cell cycle regulation mechanisms that must balance autonomic mitogenic impulses and deleterious oncogenic stress. Human papillomavirus (HPV) infection is highly prevalent in populations around the globe, whereas the incidence of cervical cancer is $0.15 \%$. Since HPV infection primes cervical keratinocytes to undergo malignant transformation, we can assume that the balance between transforming mitogenic signals and oncogenic stress is rarely attained. We showed that highly transforming mitogenic signals triggered by HRas ${ }^{\mathrm{G} 12 \mathrm{~V}}$ activity in E6E7-HPV-keratinocytes generate strong replication and oxidative stresses. These stresses are counteracted by autophagy induction that buffers the rapid increase of ROS that is the main cause of genotoxic stress promoted by the oncoprotein. As a result, autophagy creates a narrow window of opportunity for malignant keratinocytes to emerge. This work shows that autophagy is crucial to allow the transition of E6E7 keratinocytes from an immortalized to a malignant state caused by HRas ${ }^{\mathrm{G} 12 \mathrm{~V}}$.
\end{abstract}

\section{Introduction}

In developing and adult organisms, a dynamically orchestrated molecular network of stress response pathways underlies the robust homeostasis of somatic cells ${ }^{1}$. However, uncontrolled proliferation permanently compromises the cancer cell's robustness, overburdening its system of stress response pathways. This fragile balance between uncontrolled proliferation and the overloaded stress response is a phenotypic trait common to cancer cells $^{2,3}$. During the onset and development of oncogenesis, cells in the transition to malignant transformation phenotype must adapt their stress response pathways to

Correspondence: Eduardo Cararo-Lopes (edu.llopes@gmail.com) or Hugo A. Armelin (haarmelin@iq.usp.br)

${ }^{1}$ Center of Toxins, Immune-response and Cell Signaling, Instituto Butantan, São Paulo, SP 05503-900, Brazil

${ }^{2}$ Department of Biochemistry, Instituto de Química, Universidade de São Paulo, São Paulo, SP 05508-000, Brazil

Full list of author information is available at the end of the article Edited by D. Aberdam new demands of an uncontrolled proliferation surge, which lead to growing tumors or cell death.

Cervical cancer is the fourth most common cancer in women. In 2018, this disease affected 570,000 women killing $311,000^{4}$. Prior HPV infection renders cervical keratinocytes prone to malignant transformation driven by Ras oncogene mutations ${ }^{5}$. Ras is a small GTPase responsible in connecting the signal transduction from membrane tyrosine kinase receptors to protein kinase cascades $^{6}$. The KRas isoform is found in $75 \%$ of all cases of cancer in which Ras is mutated ${ }^{7,8}$; nevertheless, in HPV-primed keratinocytes, leading to head-neck and cervical cancers, HRas plays an important role ${ }^{9-11}$.

Although HPV is the most common sexually transmitted disease, only a small proportion of infected women develop cervical cancer or its precursor lesions ${ }^{4,5}$. This implies that, in vivo, human HPV-primed keratinocytes must undergo severe oncogenic stress during oncogenesis. To experimentally analyze this phenomenon, we evaluated a cell culture model of malignant transformation. As a first

\section{(c) The Author(s) 2021, corrected publication 2021}

(c) (i) Open Access This article is licensed under a Creative Commons Attribution 4.0 International License, which permits use, sharing, adaptation, distribution and reproduction cc) in any medium or format, as long as you give appropriate credit to the original author(s) and the source, provide a link to the Creative Commons license, and indicate if changes were made. The images or other third party material in this article are included in the article's Creative Commons license, unless indicated otherwise in a credit line to the material. If material is not included in the article's Creative Commons license and your intended use is not permitted by statutory regulation or exceeds the permitted use, you will need to obtain permission directly from the copyright holder. To view a copy of this license, visit http://creativecommons.org/licenses/by/4.0/. 
and necessary step, primary cultures of human keratinocytes were previously immortalized by constitutive expression of E6E7/HPV16 genes, which promote degradation of p53 and pRb proteins. Posteriorly, the E6E7 keratinocytes were subjected to malignant transformation triggered by HRas ${ }^{\mathrm{G} 12 \mathrm{~V}}$ expression ${ }^{12-14}$. However, the molecular mechanisms underlying the transition from immortalized to malignant transformed E6E7/HPV keratinocytes were not identified, particularly the role of autophagic pathways ${ }^{15}$.

Autophagy is a prosurvival mechanism responsible for the degradation and recycling of cytosolic contents, including protein complexes and organelles ${ }^{16}$. This process can provide substrates to keep cellular homeostasis in cases of high energetic and anabolic demand regularly found during oncogenesis ${ }^{17}$ (e.g., to maintain nucleotide pools ${ }^{18}$ ). Moreover, autophagy promotes clearance of dysfunctional mitochondria in cancer cells preventing the accumulation of reactive oxygen species $(\mathrm{ROS})^{19}$. Nonetheless, uncontrolled autophagic flux can also promote cell death ${ }^{20-23}$.

Here, we report quantitative analyses of a cell culture model consisting of an E6E7/HPV-immortalized human keratinocyte (hereafter E6E7 keratinocytes) conditionally subjected to ER:HRas ${ }^{\mathrm{G} 12 \mathrm{~V}}$ expression upon $4 \mathrm{OH}-$ tamoxifen (4OHT) induction. This experimental design allowed fine-tuning modulation of estrogen-receptorinducible form ER:HRas ${ }^{\mathrm{G} 12 \mathrm{~V}}$ activity, during the transition from immortalized to malignant transformed E6E7 keratinocytes.

\section{Results}

High HRas ${ }^{\mathrm{G} 12 \mathrm{~V}}$ activity caused severe oncogenic stress in E6E7 keratinocytes

We transduced E6E7 keratinocytes with a constitutively expressed HRas ${ }^{\mathrm{G} 12 \mathrm{~V}}$ oncogene construction aiming to probe into a potential transformation barrier in this type of human cells. Four days after HRas ${ }^{\mathrm{G} 12 \mathrm{~V}}$ transduction, cells showed remarkably high levels of HRas ${ }^{\mathrm{G} 12 \mathrm{~V}}$ and PERK1/2 compared with control cells transduced with empty vector control (EV) (Supplementary Fig. S1A). In addition, HRas ${ }^{\mathrm{G} 12 \mathrm{~V}}$-transduced cultures displayed aberrant morphology with several vacuoles, low proliferation, and loss of viability (Supplementary Fig. S1B). However, 30 days after transduction, HRas ${ }^{\mathrm{G} 12 \mathrm{~V}}$ and P-ERK1/2 levels markedly decreased in $\mathrm{HRas}^{\mathrm{G} 12 \mathrm{~V}}$-transduced cells, and signs of crisis were no longer observed. Moreover, by this time, HRas ${ }^{\mathrm{G} 12 \mathrm{~V}}$-transduced cells showed higher proliferation rates and increased saturation density compared with EV (Supplementary Fig. S1C, S1D). These results suggested that high HRas ${ }^{\text {G12V }}$ levels in E6E7 keratinocytes cause strong oncogenic stress, and may lead to the selection of low-expressing HRas ${ }^{\mathrm{G} 12 \mathrm{~V}}$ keratinocytes with malignant traits.
We transduced the ER:HRas ${ }^{\mathrm{G} 12 \mathrm{~V}}$ in E6E7 keratinocytes, yielding the inducible sublineages (SLis) (Fig. 1A and Supplementary Fig. S1E, S1F). 4OHT dose-response curves showed ER:HRas ${ }^{\mathrm{G} 12 \mathrm{~V}}$ expression increasing from negligible levels to a plateau at $50 \mathrm{nM}$ of $4 \mathrm{OHT}$ (Fig. 1A). The activation of the downstream proteins ERK1/2 and Akt also peaked at $50 \mathrm{nM}$. To check whether the HRas ${ }^{\mathrm{G} 12 \mathrm{~V}}$ activity was dependent on an external growth factor, we induced ER:HRas ${ }^{\mathrm{G} 12 \mathrm{~V}}$ keratinocytes in two different media compositions, with and without EGF and pituitary extract supplementation. HRas ${ }^{\mathrm{G} 12 \mathrm{~V}}$ activity in the form of ER: HRas $^{\text {G12V }}$-GTP concentration was shown to be dependent on growth factor supplementation (Fig. 1B).

In complete media, doses of the inductor ranging from 5 to $100 \mathrm{nM}$ impaired cell proliferation in a dose-dependent manner (Fig. 1C). Moreover, the cytomorphological signs of crisis were also dose-dependent on HRas ${ }^{\mathrm{G} 12 \mathrm{~V}}$ activity (Supplementary Fig. S2A). Interestingly, in nonsupplemented culture media, the addition of $50 \mathrm{nM}$ of $4 \mathrm{OHT}$ caused a slight growth increase over 10 days (Fig. 1D), whereas this concentration of the inductor blocked cell proliferation and induced cell death by day four in complete media (Fig. 1D, E). These results showed that E6E7 keratinocytes are toxically sensitive to high levels of HRas ${ }^{\text {G12V }}$ activity.

ER:HRas ${ }^{G 12 V}$ keratinocytes maintained in 20,50 , and $100 \mathrm{nM}$ of $4 \mathrm{OHT}$ were all dead in 3-6 weeks (Supplementary Fig. S3A). However, cells maintained in 5 and $10 \mathrm{nM}$ of $4 \mathrm{OHT}$ were resistant to $\mathrm{HRas}^{\mathrm{G} 12 \mathrm{~V}}$-inducible activity for 6 months. These survivor sublineages (LTE5 and LTE10) exhibited a relative ER:HRas ${ }^{\mathrm{G} 12 \mathrm{~V}}$-induction ceiling about tenfold lower than their parental inducible ER: HRas ${ }^{\mathrm{G} 12 \mathrm{~V}}$ keratinocytes (Supplementary Fig. S3B). Moreover, it is noteworthy that after this long-term selection, ER: $\mathrm{HRas}^{\mathrm{G} 12 \mathrm{~V}}$ induction with $5-50 \mathrm{nM}$ of $4 \mathrm{OHT}$ no longer caused cytotoxicity in the LTE5 (Supplementary Fig. S3C), it rather increased saturation density (Supplementary Fig. S3D), contrary to the inducible parental lineage ER: HRas ${ }^{\text {G12V }}$ keratinocytes (Supplementary Fig. S3E). Altogether, these results suggested that high HRas ${ }^{\mathrm{G} 12 \mathrm{~V}}$ activity was a barrier hardly tolerated during the malignant transformation transition of E6E7 keratinocytes.

\section{In E6E7 keratinocytes, high levels of HRas ${ }^{\mathrm{G} 12 \mathrm{~V}}$ activity cause cell cycle arrest and late cell death}

The cell proliferation inhibition caused by $\mathrm{HRas}^{\mathrm{G} 12 \mathrm{~V}}$ activity in this ER:HRas ${ }^{\mathrm{G} 12 \mathrm{~V}}$ keratinocytes model (Fig. 2A) likely involved cell cycle arrest. We pulse-labeled DNA and analyzed the cell cycle dynamics (Fig. 2B-D). The results showed that $\mathrm{G} 1 \rightarrow \mathrm{S}$ transition was blocked after $24 \mathrm{~h}$ of $4 \mathrm{OHT}$ induction since the S-phase subpopulation plummeted to negligible size by day 2 . However, the increased number of 4OHT-induced cells arrested in G2/ $\mathrm{M}$ indicated an additional cell cycle blockage. Intriguingly, 


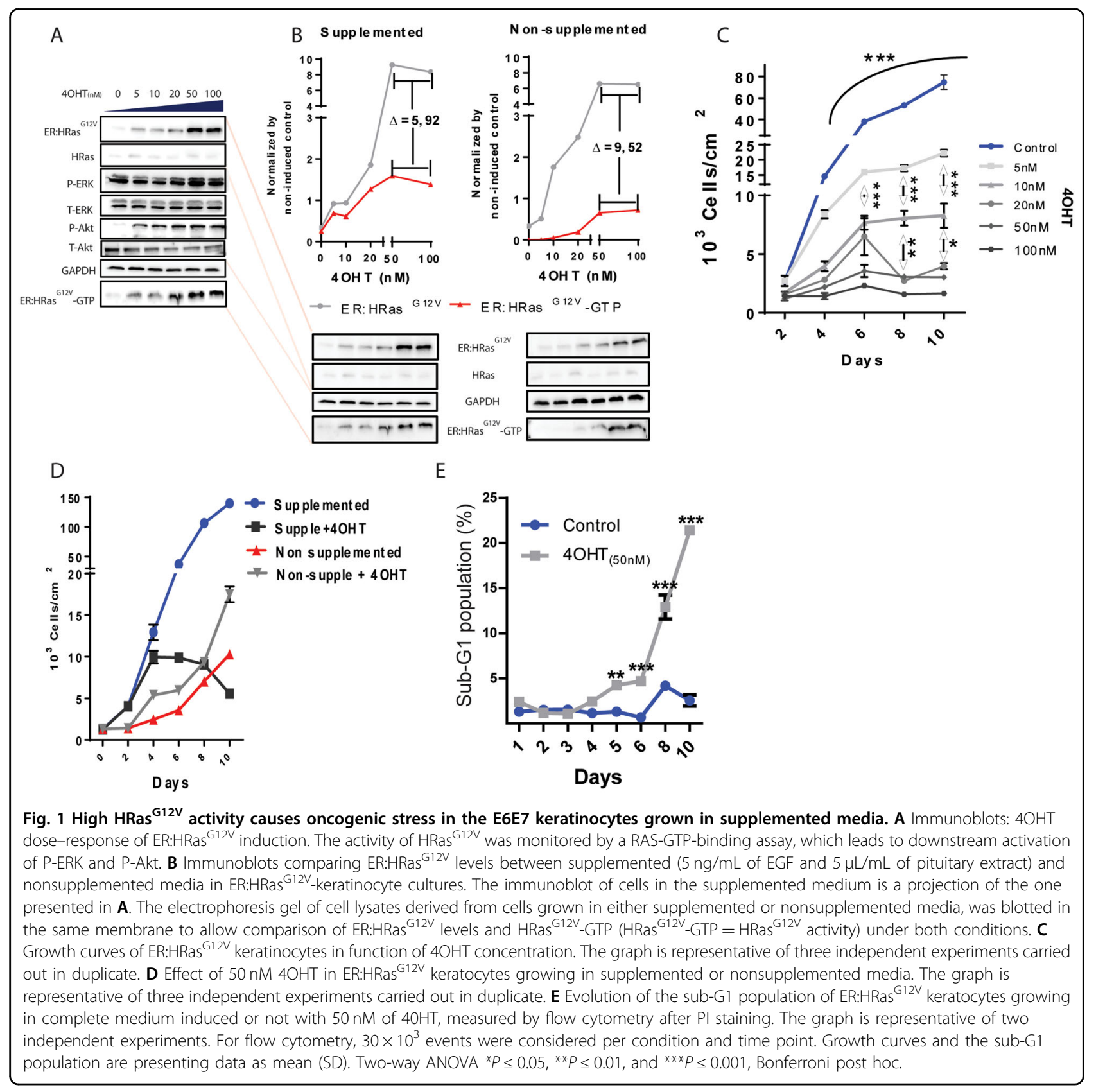

immunoblotting results showed no alterations in the levels of physiological inhibitors of G1-phase progression (p19 and p16) in these 4OHT-induced cells (Fig. 2E).

The G2/M arrest suggested the presence of DNA damage caused by the HRas ${ }^{\mathrm{G} 12 \mathrm{~V}}$-induced activity. To evaluate the presence of DNA damage in ER:HRas ${ }^{G 12 V}$ keratinocytes, we carried out a TUNEL assay. We found that on the 6th day of induction with $50 \mathrm{nM}$ of $4 \mathrm{OHT}$, cells displayed nearly $100 \%$ of TUNEL-positive cells (Fig. 3A and Supplementary Fig. S4).

A possible explanation for DNA breaks observed in ER: $\mathrm{HRas}^{\mathrm{G} 12 \mathrm{~V}}$ keratinocytes is due to an over mitogenic signal triggered by high $\mathrm{HRas}^{\mathrm{G} 12 \mathrm{~V}}$ activity. High proliferative rates enhance the replication stress present in tumor cells ${ }^{3,24}$. This could lead to genomic instability and DNA breaks if the replication stress response is not able to completely repair the DNA damage, such as exposure of long tracts of singlestranded DNA (ssDNA), which is a primary signal of this type of stress ${ }^{25}$. Thus, to verify the presence of replication stress, we measured the ssDNA exposure through a nativeBrdU immunofluorescence assay ${ }^{26}$. We found an increased number of BrdU foci in DNA in 4OHT-induced cells from days 1 to 8 (Supplementary Fig. S5); by day 6, 30\% of cells displayed more than $50 \mathrm{BrdU}$ foci per cell; on the contrary, 


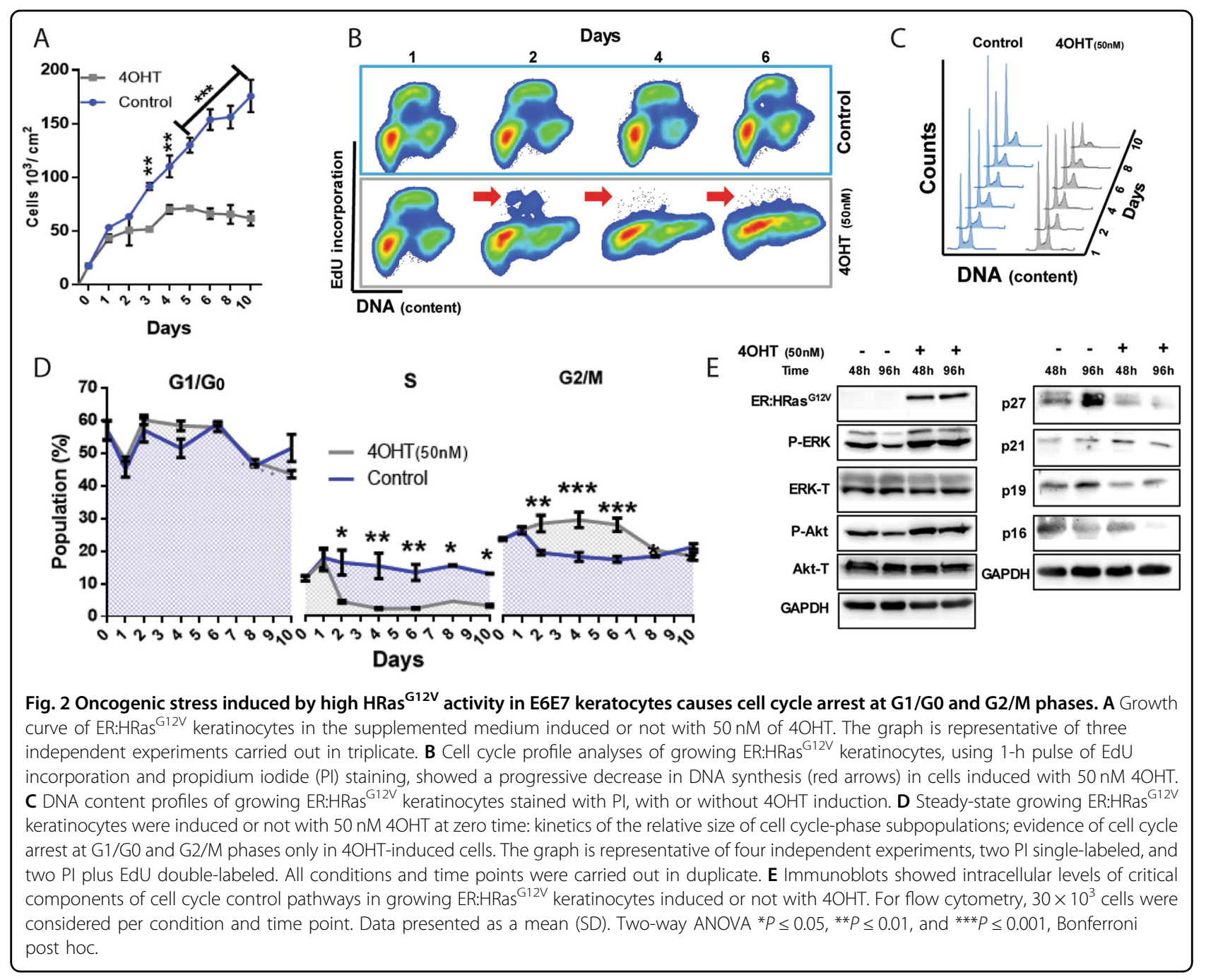

uninduced cells exhibited negligible basal levels of BrdU foci (Fig. 3B).

Kinetic flow cytometry analyses of keratinocytes under high HRas ${ }^{\mathrm{G} 12 \mathrm{~V}}$ activity showed cell death increase in a dose-dependent manner from day 4 to day 10 of induction (Fig. 3C). Furthermore, annexin-V/PI double-stained profiles of cells induced with $50 \mathrm{nM}$ of $4 \mathrm{OTH}$ for up to 10 days confirmed cell death (Fig. 3D), which was not rescued by the treatment with the caspase inhibitor ZVAD (Fig. 3E), showing that the cell death is independent of caspase activity. Thus, these results presented the progressive oncogenic stress crisis triggered by $\mathrm{HRas}^{\mathrm{G} 12 \mathrm{~V}}$ overactivity in E6E7 keratinocytes, which comprises replication stress, cell cycle arrest, and late cell death.

\section{Oxidative stress underpinned the damaging effects of high HRas $^{\text {G12V }}$ activity in E6E7 keratinocytes}

DCF fluorescence labeling indicated a HRas ${ }^{\mathrm{G} 12 \mathrm{~V}}$ dosedependent elevation of ROS in induced ER:HRas ${ }^{\text {G12V }}$ keratinocytes (Supplementary Fig. S6A). In addition,
MitoSOX fluorescence labeling evidenced mitochondrial superoxide accumulation in induced cells (Supplementary -Fig. S6B). These results confirmed that $\mathrm{HRas}^{\mathrm{G} 12 \mathrm{~V}}$ activity induced oxidative stress in E6E7 keratinocytes, suggesting a causal role in the oncogenic stress crisis described.

Treatment with the ROS scavenger NAC (N-Acetyl cysteine) reduced the levels of single-stranded DNA accumulation induced by $50 \mathrm{nM} 4 \mathrm{OHT}$ in ER:HRas ${ }^{\mathrm{G} 12 \mathrm{~V}}$ keratinocytes (Supplementary Fig. S7). The phosphorylation of both p38 and H2AX was also decreased in the presence of NAC, with no changes in the ERK activation induced by HRas ${ }^{G 12 V}$ activity (Fig. 4A). These results confirmed that $\mathrm{HRas}^{\mathrm{G} 12 \mathrm{~V}}$ activity induced oxidative stress in E6E7 keratinocytes, which account for the oncogenic stress crisis described and indicate that NAC attenuates the replication stress/DNA damage induced by high HRas ${ }^{\text {G12V }}$ activity without affecting its mitogenic signaling. NAC alleviated the cell cycle arrest induced by HRas $^{\mathrm{G} 12 \mathrm{~V}}$ activity, partly relieving the cell proliferation inhibition (Fig. 4B). Moreover, NAC partially rescued ER: 


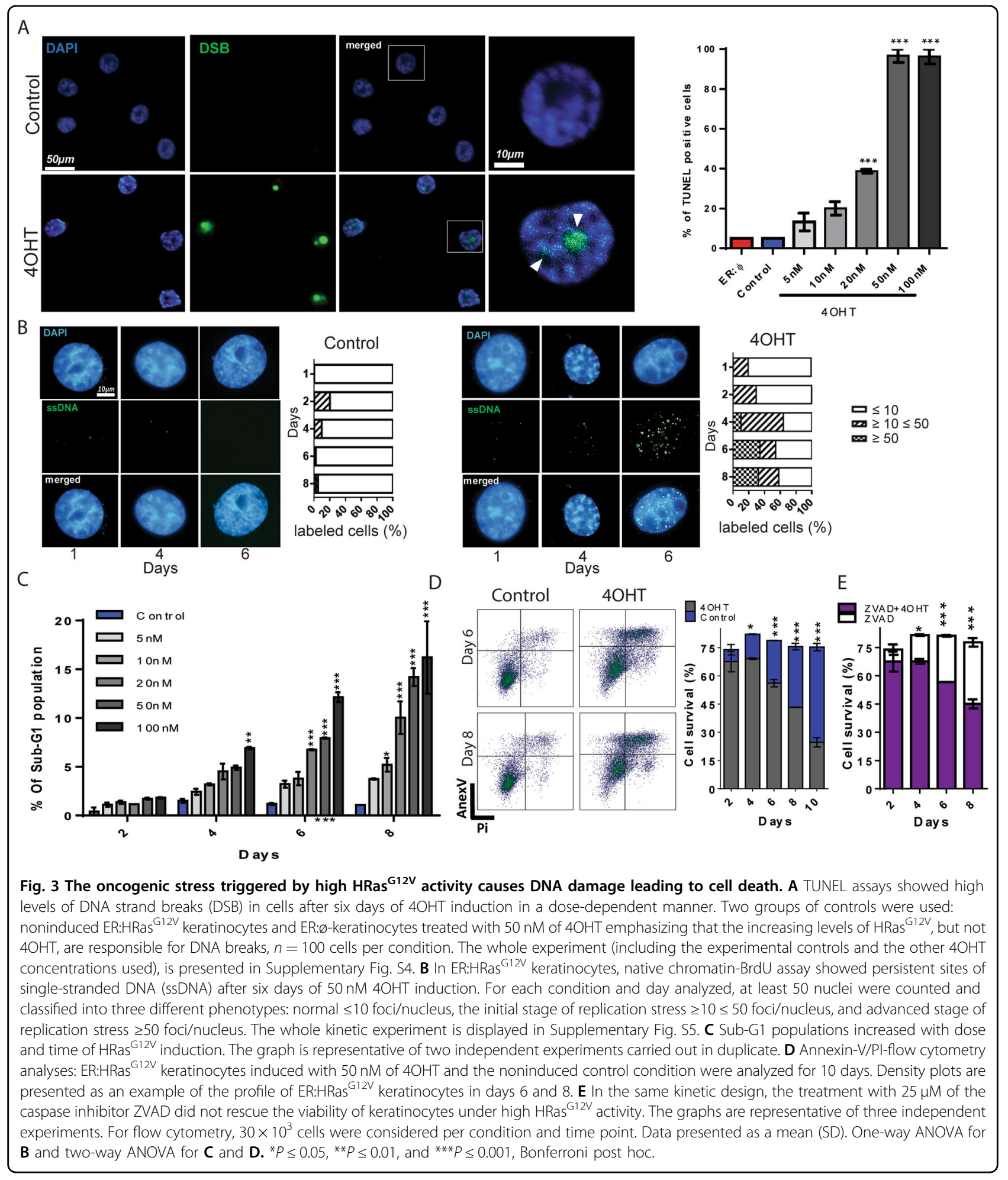

HRas ${ }^{\text {G12V }}$ keratinocytes from the cell death triggered by high HRas ${ }^{\mathrm{G} 12 \mathrm{~V}}$ activity, as shown by sub-G1 subpopulation measurements (Fig. 4C) and annexin-V/PI assays (Fig. 4D). Altogether, these results show that oxidative stress was a major cause of the oncogenic stress crisis triggered by high HRas ${ }^{\mathrm{G} 12 \mathrm{~V}}$ activity in E6E7 keratinocytes, which act in the cell cycle blockages at G1 $\rightarrow \mathrm{S}$ transition and $\mathrm{G} 2 / \mathrm{M}$ phase (Fig. 4E). 


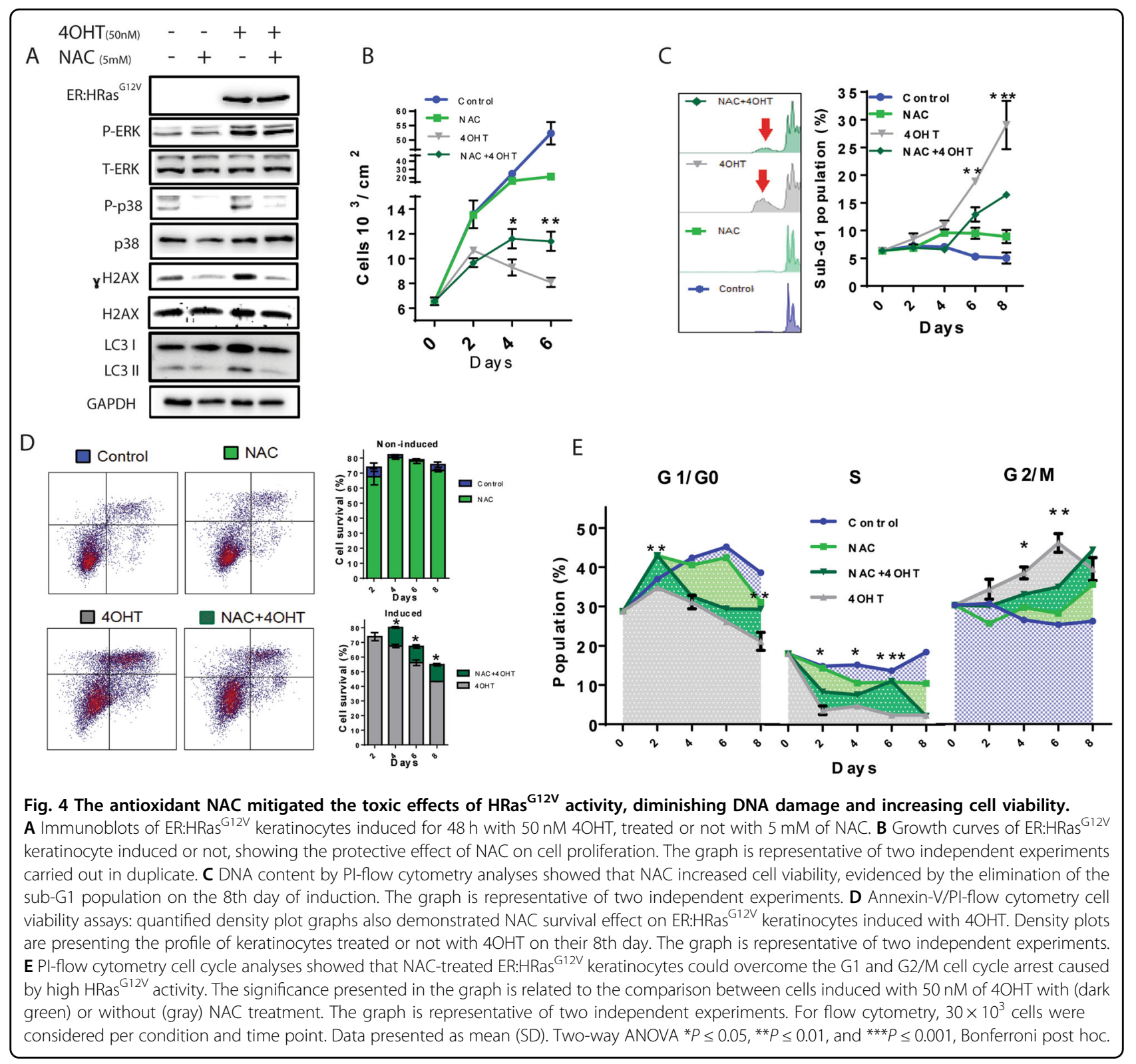

Autophagy buffers oncogenic stress triggered by HRas ${ }^{G 12 V}$ activity creating a survival and proliferative window for malignant keratinocyte surges

Induced ER:HRas ${ }^{\text {G12V }}$ keratinocytes microscopically displayed vacuoles that progressively increased in size and quantity depending on $4 \mathrm{OHT}$ concentration and time of induction (Supplementary Fig. S2). Immunofluorescence evidenced the colocalization of autophagic proteins p62 and LC3 at days 4 and 6 (Fig. 5A) after HRas ${ }^{\text {G12V }}$ induction. In addition, immunoblotting kinetics showed increased levels of LC3II, an indicator of autophagic activity, only after the peak of $4 \mathrm{OHT}$-induced HRas ${ }^{\mathrm{G} 12 \mathrm{~V}}$ expression (Fig. 5B).

These results showing autophagy upregulation following the increase in the oncogenic HRas ${ }^{\mathrm{G} 12 \mathrm{~V}}$ levels suggested that autophagy was triggered in response to HRas $^{\text {G12V }}$ activity potentially to keep the cell viability. To further investigate the role of autophagy in the induced ER:HRas ${ }^{\mathrm{G} 12 \mathrm{~V}}$ keratinocytes, we used hydroxychloroquine (CQ), an autophagy inhibitor. Immunoblotting for LC3II revealed that $48 \mathrm{~h}$ of $\mathrm{HRas}^{\mathrm{G} 12 \mathrm{~V}}$ induction increased autophagic initiation but when combined with CQ treatment also increased the accumulation of nonprocessed autophagic labeled substrates, as shown by the accumulation of p62, suggesting that HRas ${ }^{\mathrm{G} 12 \mathrm{~V}}$ activity surpassed the autophagic flux limit (Fig. 6A) ${ }^{27,28}$. After $96 \mathrm{~h}$ of HRas $^{\mathrm{G} 12 \mathrm{~V}}$ induction combined with $\mathrm{CQ}$, both the proliferation inhibition (Fig. 6B) and cell death (Fig. 6C) drastically enhanced. 
A
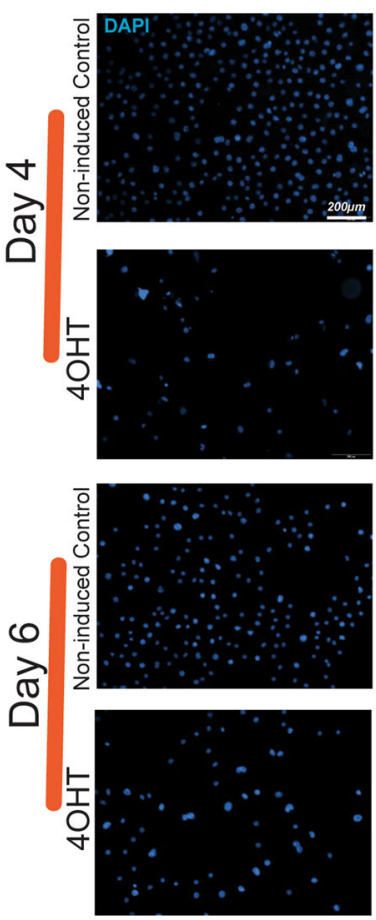

B

Time after $4 \mathrm{OHT}$
induction $\quad 0 \quad 30^{\prime \prime} 1^{\prime} \quad 5^{\prime} 10^{\prime} 15^{\prime} 30^{\prime} 1 \mathrm{~h} \quad 3 \mathrm{~h} 24 \mathrm{~h} 48 \mathrm{~h} 56 \mathrm{~h} 72 \mathrm{~h} 96 \mathrm{~h}$
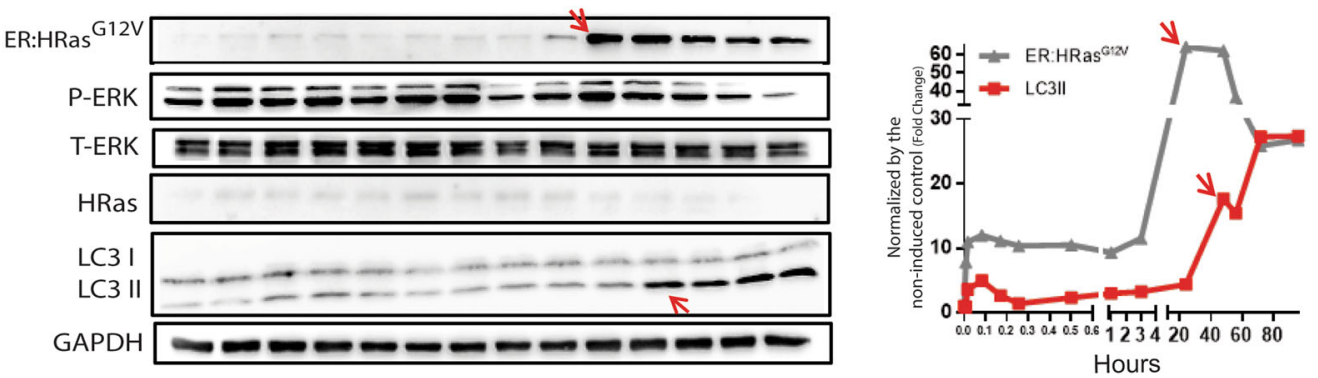

Fig. 5 Autophagic flux was increased $48 \mathrm{~h}$ after HRas ${ }^{G 12 V}$ induction. A Forty-eight hours after HRas ${ }^{G 12 V}$ induction, immunofluorescence assays (IFA) exhibited the onset of the two autophagic markers LC3 and p62, which colocalized the surrounding vacuoles, suggesting a cause-and-effect relationship between $\mathrm{HRas}^{\mathrm{G}}{ }^{12 \mathrm{~V}}$ activity and autophagy initiation. B The kinetics of this phenomenon was further clarified by immunoblots that showed HRas ${ }^{\mathrm{G} 12 \mathrm{~V}}$ induction at $24 \mathrm{~h}$ followed by LC3ll expression at $48 \mathrm{~h}$ (see red arrows), implying that the autophagy initiation was in response to the oncogenic stress caused by HRas ${ }^{\mathrm{G} 12 \mathrm{~V}}$ activity.

We established an ER:HRas ${ }^{\mathrm{G} 12 \mathrm{~V}}$ keratinocyte sublineage defective in autophagy by knocking out the gene encoding the protein ATG7 using the CRISPR-Cas9 system. In contrast with the scramble control cells (hereafter Scrb keratinocytes), the resultant knocked-out sublineage (hereafter $\triangle$ ATG7 keratinocytes) showed undetectable levels of ATG7 and no autophagy activation when induced (Fig. 6D). Upon HRas ${ }^{\mathrm{G} 12 \mathrm{~V}}$ induction, $\triangle \mathrm{ATG7}$ keratinocytes failed to process LC3I-LC3II, and the p62 levels were increased compared to Scrb keratinocytes, confirming successful ablation of the autophagic pathway. In addition, $\mathrm{HRas}^{\mathrm{G} 12 \mathrm{~V}}$ induction and MAPK-ERK1/2 activation were similar in Scrb- and $\triangle$ ATG7 keratinocytes, showing that the pattern of HRas ${ }^{\mathrm{G} 12 \mathrm{~V}}$ induction and mitogenic activation were preserved. $\triangle$ ATG7 keratinocytes turned out to be extremely sensitive to the oncogenic stress initiated by $\mathrm{HRas}^{\mathrm{G} 12 \mathrm{~V}}$ activity. Growth curves showed that the proliferation of $\triangle$ ATG7 keratinocytes was strongly inhibited even by $5 \mathrm{nM}$ of $4 \mathrm{OHT}$ induction, which was well tolerated by parental ER:HRas ${ }^{\mathrm{G} 12 \mathrm{~V}}$ keratinocytes or Scrb keratinocytes (Fig. 6E, $5 \mathrm{nM})$. This increased sensitivity to HRas ${ }^{\mathrm{G} 12 \mathrm{~V}}$ activity in $\triangle$ ATG7 keratinocytes was even more pronounced in higher concentrations of $4 \mathrm{OHT}$ (Fig. 6E, 20 and $50 \mathrm{nM}$ ). Moreover, annexin-V/PI assays demonstrated that $\triangle \mathrm{ATG} 7$ keratinocytes under induction died earlier and at higher rates than Scrb keratinocytes (Fig. 6F). 


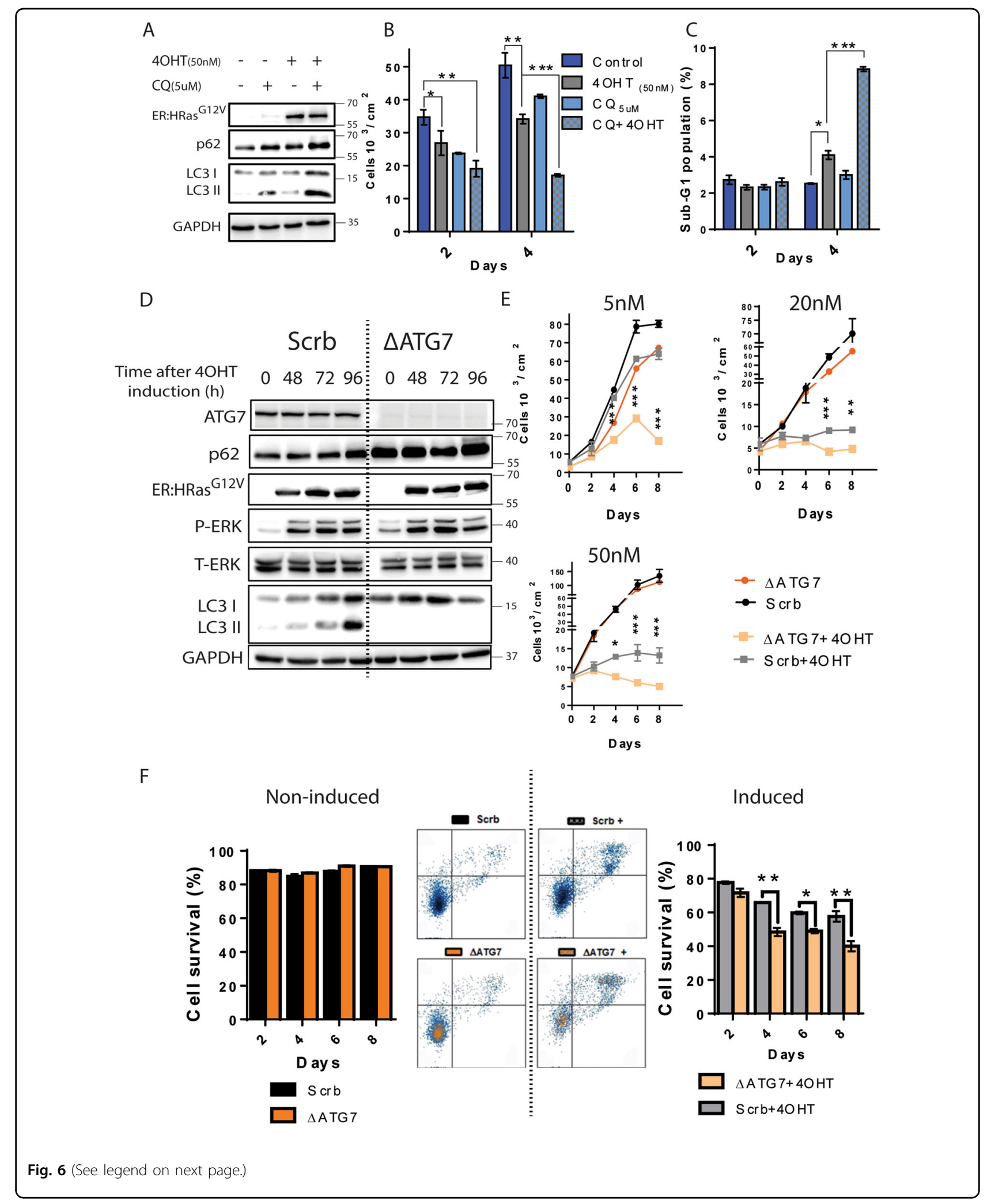


(see figure on previous page)

Fig. 6 Autophagy promoted survival in keratinocytes under oncogenic stress triggered by HRas ${ }^{G 12 V}$ activity. A Immunoblots of ER:HRas ${ }^{G 12 V}$ keratinocytes presenting autophagy markers (LC3II and p62) under $48 \mathrm{~h}$ of CQ $(5 \mu \mathrm{M})$ treatment induced or not with $40 \mathrm{OHT}(50 \mathrm{nM})$. B The growth curve of induced ER:HRas ${ }^{G 12 V}$ keratinocytes suggests loss of cell viability of keratinocytes that had their autophagy flux inhibited. The graph is representative of three independent experiments carried out in duplicate per condition and time point. C DNA content analysis by flow cytometry using PI of labeled ER:HRas ${ }^{G 12 V}$ keratinocytes showed a drastic increase of sub-G1 population in 4OHT-induced keratinocytes treated with CQ. The graph is representative of two independent experiments. D Immunoblots of ER:HRas ${ }^{\mathrm{G} 12 \mathrm{~V}}$ autophagy-defective keratinocytes ( $\triangle \mathrm{ATG7}$ keratinocytes) and their control autophagy-competent scrabble (Scrb keratinocytes). The absence of ATG7 and LC3II in $\triangle$ ATG7 keratinocytes induced with $50 \mathrm{nM}$ $4 \mathrm{OHT}$ confirmed successful knockout of the ATG7 gene and ablation of the autophagy pathway. E Growth curves using different $4 \mathrm{OHT}$ concentrations and consequently different levels of HRas ${ }^{G 12 \mathrm{~V}}$ activity. The graph is representative of three independent experiments carried out in duplicate. F Flow cytometry of cell viability assay stained with annexin-V/PI. Density plot graphs (8th day) and their quantification indicate that autophagy activity is crucial for keratinocyte survival under oncogenic stress promoted by HRas ${ }^{G 12 \mathrm{~V}}$ activity. The graph is representative of two independent experiments in which $30 \times 10^{3}$ cells were considered per condition and time point. Data presented as a mean (SD). Two-way ANOVA, ${ }^{*} P \leq 0.05,{ }^{*} P \leq 0.01$, and ${ }^{* *} P \leq 0.001$, Bonferroni post hoc.

The results of Figure 4 indicated that ROS generation was the main cause of oncogenic stress triggered by HRas $^{\text {G12V }}$ activity. These results also suggested that autophagy upregulation was a prosurvivor response, aiming to keep cell viability. Furthermore, immunoblot showed that HRas ${ }^{\mathrm{G} 12 \mathrm{~V}}$-induced keratinocytes displayed reduced levels of autophagy when cells were treated with NAC (Fig. 4A, LC3II). We compared the levels of ROS between $\triangle$ ATG7 keratinocytes and Scrb keratinocytes. By $48 \mathrm{~h}$ of induction, HRas ${ }^{\mathrm{G} 12 \mathrm{~V}}$ activity increased ROS levels in about $20 \%$ in the Scrb keratinocytes (Fig. 7AI, BI); markedly, in $\triangle \mathrm{ATG} 7$ keratinocytes, HRas ${ }^{\mathrm{G} 12 \mathrm{~V}}$ activity resulted in over $70 \%$ increase (Fig. 7AII, BII). Such elevation in the ROS levels was not found in autophagycompetent keratinocytes, even in longer time points after induction (Fig. 7AIII, BIII). Further linking the oxidative stress to the observed autophagy, NAC treatment partially prevented ROS acute increase in $\triangle \mathrm{ATG7}$ keratinocytes, protection even higher than in Scrb keratinocytes after $\mathrm{HRas}^{\mathrm{G} 12 \mathrm{~V}}$ induction, showing that the ROSbuffering effect was dependent on autophagic activity (Figs. 7A, BI, BII).

Besides the autophagy-buffering effects on ROS, elevated glycolytic levels suggested that autophagy could also be recruited in consequence of a metabolic imbalance in keratinocytes upon high HRas ${ }^{\mathrm{G} 12 \mathrm{~V}}$ activity (Fig. 7C). In these conditions, autophagy can be mobilized to relieve this metabolic imbalance by supplying cells with essential substrates ${ }^{18,29}$. Thus, we fed induced ER:HRas ${ }^{\text {G12V }}$ keratinocytes with deoxynucleosides for 6 days. Deoxynucleoside feeding rescued ER:HRas ${ }^{\mathrm{G} 2 \mathrm{~V}}$ keratinocytes from death but did not recover cell proliferation, suggesting that nucleotide pool deregulation was part of the oncogenic stress triggered by high HRas ${ }^{\mathrm{G} 12 \mathrm{~V}}$ activity (Fig. 7D).

Altogether, these results revealed that autophagy prevents HRas ${ }^{\mathrm{G} 12 \mathrm{~V}}$-dependent rapid ROS generation, opening a window for survival and proliferation of E6E7 keratinocytes under stress caused by high $\mathrm{HRas}^{\mathrm{G} 12 \mathrm{~V}}$ activity. This window would allow the selection of malignant HPV-primed keratinocytes, making autophagy a tumor promoter agent in this context (Fig. 8).

\section{Discussion}

Mutated HRas is found in approximately 230,000 cases of cancer globally ${ }^{11}$. However, as we have shown, the oncogenic potential of mutated HRas is limited by its own activity. We demonstrated that different levels of HRas $^{\mathrm{G} 12 \mathrm{~V}}$ activity are responsible for different cell fates, which were determined by the oncogenic stress levels tolerated by keratinocytes. In E6E7 keratinocytes, high HRas ${ }^{\mathrm{G} 12 \mathrm{~V}}$ activity initiated a chain of stresses, leading to discoordination of the mitogenic signaling that propagates to replication impairment and oxidative stress, both responsible for DNA damage.

We demonstrated that elevated HRas ${ }^{\mathrm{G} 12 \mathrm{~V}}$ activity strongly signaled cell cycle progression as indicated by MAPK stimulation and p16 and p19 inhibition (Fig. 2D, C). Paradoxically, $48 \mathrm{~h}$ after induction rather than progressing, the keratinocytes remained blocked in the G1/G0 phase (Fig. 2), exhibiting symptoms of mitogenic stress. Ras is a causative agent of mitogenic stress since it can deregulate cell cycle checkpoints through the Raf/ MEK/ERK axis ${ }^{30,31}$. Besides, sustained Ras activity can mediate genomic instability ${ }^{32}$. In this scenario, genomic instability was caused by defects in the spindle assembly checkpoints that became an important source of DNA damage signaling to $\mathrm{p} 53$, which resulted in interruption of cell cycle progression and potentially in cell death ${ }^{32}$. In lung cells, the transition from hyperplastic to malignant phenotype is associated with genomic instability that positively selects cells with p53-inactivating mutations $^{33}$. Furthermore, functional p53- signaling is the base to explain the better prognostics found in HPVhead-neck cancers in comparison with $\mathrm{HPV}+$ ones from the same type $\mathrm{e}^{34,35}$.

In the case of E6E7 keratinocytes, p53 and pRb were degraded by E6E7/HPV proteins (Supplementary Fig. $\mathrm{S} 1 \mathrm{G}, \mathrm{S} 1 \mathrm{H}, \mathrm{S} 1 \mathrm{I})$; however, these cells under high HRas ${ }^{\mathrm{G} 12 \mathrm{~V}}$ 


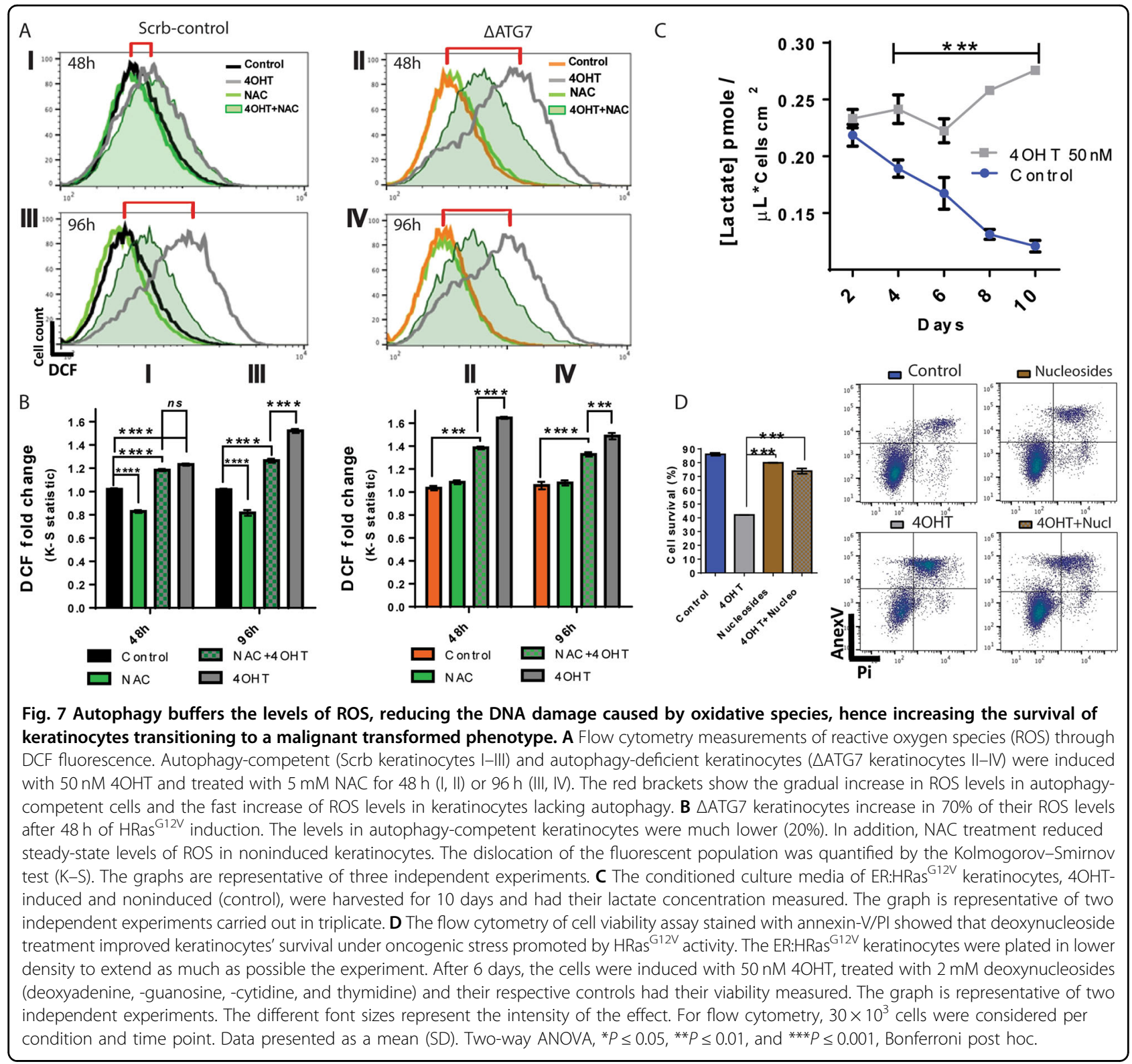

activity were driven to cell cycle arrest followed by death. We hypothesize that the genomic instability due to sustained high HRas ${ }^{\mathrm{G} 12 \mathrm{~V}}$ activity is the cause of a genomic crisis that typically occurs in cells transitioning to the malignantly transformed stage that is characterized by mitotic arrest, hyperstimulation of autophagy, and cell death $^{15,36}$, events systematically present in E6E7 keratinocytes under high HRas ${ }^{\mathrm{G} 12 \mathrm{~V}}$ activity as we have shown (Figs. 2 and 5). Moreover, the degradation of p53 (Supplementary Fig. $\mathrm{S} 1 \mathrm{H}$ ) and the high index of cell death under high HRas ${ }^{\mathrm{G} 12 \mathrm{~V}}$ activity, even when the caspase inhibitor ZVAD is used (Fig. 3E), suggested that the genomic crisis allied to high levels of ROS might be responsible for a nonapoptotic cell death independent on caspase activation. Besides, annexin-V/PI assays showed that the wide majority of nonviable keratinocytes are double-labeled (Figs. 3D, 4D, and 6F), which is consistent with abrupt rupture of the cytoplasmatic membrane that is one of the main hallmarks of necrosis ${ }^{37}$. To conclude, the high levels of ROS (Fig. 6), the rescue of cell viability using the ROS scavenger NAC, and the potential metabolic imbalance (Figs.4 and 7C/D) allow us to propose that ferroptosis, a specific form of regulated necrosis ${ }^{38}$, might have been trigged as an additional tumor suppressor mechanism that superposes the deficiency of canonical checkpoint signaling when E6E7 keratinocytes are exposed to high HRas ${ }^{\mathrm{G} 12 \mathrm{~V}}$ activity, but further evidence is necessary to support such proposal. 


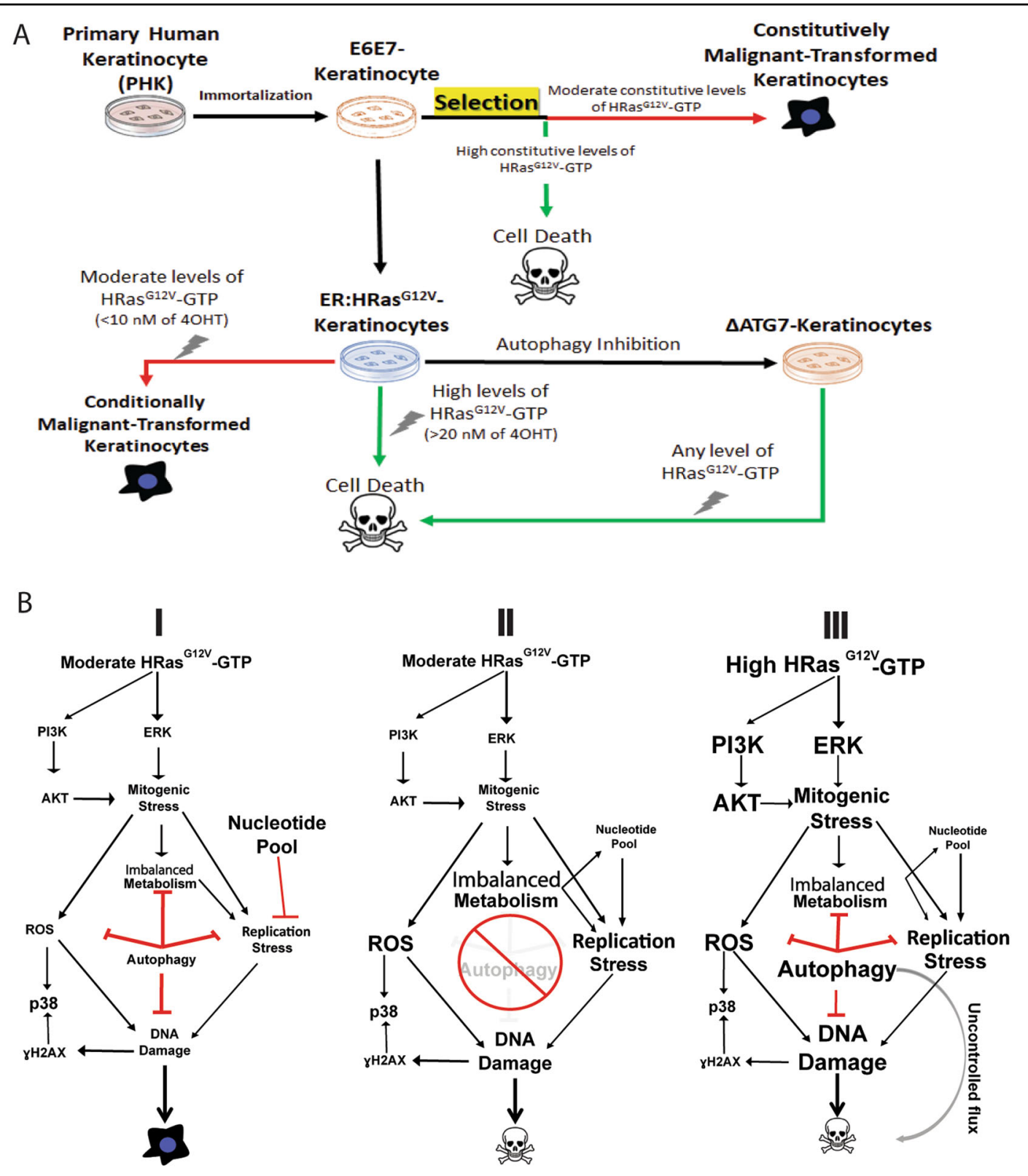

Fig. $8 \mathrm{HPV}$-primed keratinocytes require autophagy to counteract the oncogenic stress triggered by HRas ${ }^{\mathrm{G} 12 \mathrm{~V}}$ activity during the malignant transformation transition. A Step-by-step of the models generated and the role of HRas ${ }^{G 12 \mathrm{~V}}$ activity in their fates. Note that the different levels of inducible ER:HRas ${ }^{G 12 \mathrm{~V}}$ activity are mimicking the fates observed in the constitutive ones. In the constitutive model, we could observe only the product of a random selection of cells presenting low levels of HRas ${ }^{G 12 \mathrm{~V}}$ activity. Nonetheless, using the inducible model, we were able to observe the phenomenon responsible for such selection. B Mechanistic model presenting the challenge that HPV-primed keratinocytes, in the transition to a malignant transformed phenotype, must bypass according to the intensity of oncogenic stress (ROS, imbalanced metabolism, replication stress, and DNA damage). The intensity of the oncogenic stress is determined by different levels of HRas ${ }^{\mathrm{G} 12 \mathrm{~V}}$ activity and it is counterbalanced by autophagic activity in a different fashion: (I) only a moderate level of HRas ${ }^{G 12 \mathrm{~V}}$ activity is supported by immortalized E6E7 keratinocytes since the autophagy activity, also moderate, is capable of buffering the oncogenic stress generated. (II) However, without the recruitment of autophagy, any level of oncogenic stress is not tolerated, proving that autophagy is recruited primarily as a safeguard mechanism. (III) On the other hand, high levels of HRas ${ }^{\mathrm{G} 12 \mathrm{~V}}$ activity generate unbearable oncogenic stress followed by the activation of autophagy over the cell capacity of processing that becomes an additional source of stress leading to cell death. The different font sizes are expressing the levels of cell signaling/events observed. 
Another source of DNA damage caused by high HRas ${ }^{\mathrm{G} 12 \mathrm{~V}}$ activity is the replication stress that could be compounded by different molecular events: increased firing origin of replication, impaired fork progression ${ }^{39,40}$, depleted nucleotide pool $^{41}$, and stimulated replication-transcription conflicts $^{42}$. Nonetheless, our findings suggested that the predominant factor that led to replication impairment and DNA damage was oxidative stress. We demonstrated that E6E7 keratinocytes under high $\mathrm{HRas}^{\mathrm{G} 12 \mathrm{~V}}$ activity treated with NAC considerably reduced the levels of ssDNA and $\gamma \mathrm{H} 2 \mathrm{AX}$ (Supplementary Fig. S7 and Fig. 4A), allowing these cells to overcome the G1/G0 blockage, to progress throughout the $\mathrm{S}$ phase, and delay the blockage in G2/M (Fig. 4E).

We showed that the limited improvement observed in NAC treatment was linked to autophagic activity as suggested by LC3II- and ROS-reduced levels in induced keratinocytes treated with NAC (Figs. 4A and 7A/B). Autophagy buffers the acute generation of ROS caused by HRas ${ }^{G 12 V}$ activity enhancing the keratinocyte viability. In autophagy-competent E6E7 keratinocytes (Scrb keratinocytes), the ROS levels increased but never reached the threshold of autophagy-deficient E6E7 keratinocytes ( $\triangle$ ATG7 keratinocytes). We hypothesized that the main source of the observed ROS is mitochondria, as suggested by the increased levels of mitochondrial superoxide (Supplementary Fig. S6A). Besides, oncogenic stress can cause DNA damage mediated by mitochondrial $\operatorname{ROS}^{19,43,44}$. Moreover, mitophagy is an important mechanism to prevent the surge/increases of ROS clearing-damaged mitochondria ${ }^{22,45-47}$. Thus, we proposed that in E6E7 keratinocytes under HRas ${ }^{\mathrm{G} 12 \mathrm{~V}}$ activity, autophagy could be acting in the clearance of damaged mitochondria softening the deleterious effects of $\operatorname{ROS}^{47,48}$.

The context dependence of autophagy in cancer cells has been largely discussed ${ }^{22,49-52}$. Some authors attribute to autophagy a potential for cell death driving ${ }^{38,53}$; however, in most cases where autophagy is associated with cell death, the mechanism is activated as a prosurvival attempt $^{54}$. Here, we are proposing that in E6E7 keratinocytes, autophagy was recruited as a prosurvival mechanism to mitigate the oncogenic stress caused by $\mathrm{HRas}^{\mathrm{G} 12 \mathrm{~V}}$ activity; however, only in moderate oncogenic activity, the mechanism can support the transition from immortalized to the malignant transformed phenotype.

This is a convincing proposition when we consider that E6E7 keratinocytes were unviable under any level of HRas ${ }^{G 12 V}$ activity when autophagy was blocked (Fig. 6). Despite the essential role of autophagy in keratinocytes transitioning from immortalized to malignant state, its intense and continuous recruitment overloaded the system causing an uncontrolled flux (Figs. 5B and 6D), demonstrated by the accumulation of p62 (Figs. 5A and $6 \mathrm{~A} / \mathrm{D})$. The accumulation of p62 by itself is highly toxic, causing even more generation of ROS, which might contribute to the phenotype observed ${ }^{55,56}$. Therefore, we concluded that autophagy is initiated as a protective mechanism increasing cell survival; however, sustaining intense autophagic induction caused by acute ROS surges generates an autophagic flux beyond the cell processing capacity. As a result, autophagy became an additional source of stress.

Finally, cells exposed to HRas ${ }^{\mathrm{G} 12 \mathrm{~V}}$ activity can be aided by metabolic reprogramming increasing the glycolytic activity through the MAPK and PI3K axes. This metabolic reprogramming helps in the generation of biomass such as amino acids and nucleotides ${ }^{57}$. Our results showed that E6E7 keratinocytes under HRas ${ }^{\mathrm{G} 12 \mathrm{~V}}$ activity highly signaled MAPK and PI3K, and might be responsible for a metabolic shift (Figs. 1A, 2E, 4A, and 6D). In addition, the increased concentration of lactate in the cell culture medium suggested that E6E7 keratinocytes under high HRas $^{\mathrm{G} 12 \mathrm{~V}}$ activity were pushed to reprogramming its metabolism to aerobic glycolysis. Likewise, the elevated mitogenic signal could increase the number of DNA replication origins fired, further stressing the limited levels of deoxynucleotide pools causing genomic instability and consequent loss of cell viability ${ }^{58}$. As shown in Fig. 7D, treatment with deoxynucleosides partially rescued the viability of induced keratinocytes.

In conclusion, our results showed that high levels of HRas ${ }^{\text {G12V }}$ activity are not tolerated by E6E7 keratinocytes under any circumstances for two reasons: first, deleterious levels of mitogenic, replication, and ROS stresses responsible for high genotoxicity; second, recruitment and activation of autophagy beyond the processing capacity of the cell system, causing accumulation of toxic content not properly processed (Fig. 8). These results per se are proposing an alternative molecular approach to defeat malignantly transformed cells, that consists in the imposition of even higher levels of mitogenic signals while autophagy is blocked, which could be a promising therapeutic strategy when limiting cell growth using mitogenactivated protein kinase inhibitors proves to be ineffective or refractory.

\section{Methods}

Transduction, parental cells, and sublineage cultures

All parental cells and sublineages listed below were grown in KSFM medium (Thermo Fisher ${ }^{\circ}$ ) supplemented with recombinant epidermal growth factor $5 \mathrm{ng} / \mathrm{ml}$, bovine pituitary extract $50 \mathrm{mg} / \mathrm{ml}$ (except when otherwise indicated) and incubated at $37^{\circ} \mathrm{C}$ in $5 \% \mathrm{CO}_{2}$ atmosphere.

\section{Immortalization of primary human keratinocytes with E6E7-HPV16 proteins}

Primary foreskin human keratinocytes (PHK) (Lonza Walkersville, Inc., Walkersville, MD) were transduced 
with pLXSN-encoding E6E7-HPV16 proteins. After $24 \mathrm{~h}$ of acute transduction, transduced keratinocytes were selected using $300 \mu \mathrm{g} / \mathrm{mL}$ of G418. The retrovirus pLXSN was kindly provided by Dr. Denise Galloway (Fred Hutchinson Cancer Research Center, Seattle, WA), which was previously described ${ }^{59}$.

\section{Constitutive (SLCs) and inducible (SLis) keratinocyte sublineages}

PHK immortalized by E6E7/HPV16 proteins was transduced with retrovirus constructs for $48 \mathrm{~h}$. pBabepuroHRas ${ }^{\mathrm{G} 12 \mathrm{~V}}$ was utilized for constitutive expression (SLcs) and pBabepuro-ER:HRas ${ }^{\mathrm{G} 12 \mathrm{~V}}$, for inducible expression sublineages (SLis) (Supplementary Fig. S1). After this period, transduced cultures were selected using $2.5 \mu \mathrm{g} / \mathrm{mL}$ of puromycin (Invitrogen ${ }^{\odot}$ ). Three independent clones were generated for each sublineage. Additionally, two independent empty controls were generated pBabe- $\varnothing$ and pBabe-ER: $\varnothing$ for constitutive and inducible sublineages, respectively. Concentrations from $5 \mathrm{nM}$ to $100 \mathrm{nM}$ of $4 \mathrm{OHT}$ proved to be innocuous in the parental E6E7 keratinocytes and ER:Økeratinocytes (Supplementary Fig. S1 J/L) emphasizing that the results obtained are exclusively related to HRas ${ }^{G 12 \mathrm{~V}}$ activity and not the inductor 4OHT. All treatments, concentrations, and vehicles of dilution (used in the controls) are indicated in Supplementary Table 1.

\section{Cas9-mediated ATG7 knockout}

To knock out the ATG7 gene in ER:HRas ${ }^{\text {G12V }}$ keratinocytes, we designed and tested two different gRNAs ( $\triangle$ ATG7I and $\triangle$ ATG7II) using the CRISPR design tool (http://crispr.mit.edu/). A control gRNA (Scrb keratinocytes) that normally expresses ATG7 was also designed. The sequences are presented in Supplementary Table 1. Oligos were cloned into the LentiCRISPR v2 plasmid (a gift from Feng Zhang, Addgene plasmid \# 52961) as described in Sanjana et al. ${ }^{60}$. For lentivirus production, LentiCRISPR v2 constructs, psPAX2 (a gift from Didier Trono, Addgene plasmid \# 12260), and pCMV-VSV-G (a gift from Bob Weinberg, Addgene plasmid \# 8454) were transfected into HEK293T cells using lipofectamine 3000 reagents according to the manufacturer's protocol. Fortyeight hours after transfection, viral supernatant was collected, filtered, and applied to ER:HRas ${ }^{\mathrm{G} 12 \mathrm{~V}}$ keratinocytes after the addition of $8 \mu \mathrm{g} / \mathrm{ml}$ polybrene. The knockout was tested after 7 days since both gRNAs showed a high efficiency; all the experiments were performed using the sublineage ER:HRas ${ }^{\text {G12V }}$ keratinocyte- $\triangle$ ATG7I, hereafter $\triangle$ ATG7 keratinocytes.

\section{Growth curves and cell saturation density assay}

For growth curve assays, $7 \times 10^{3}$ cells $/ \mathrm{cm}^{2}$ were plated (except when differently stated) in $\operatorname{Costar}^{\circledR}$ six-well plates. Forty-eight hours later, a six-well plate was collected to determine P0. This procedure was done to eliminate the lag phase of these cells and observe the effects of treatment and/ or induction in the exponential phase. For maximum cell density saturation assays, $20 \times 10^{3}$ cells $/ \mathrm{cm}^{2}$ were plated. After 10 days (P10), the cultures reached their saturation density. The induction using 4-hydroxytamoxifen (4OHT) was initiated in P0, for the growth curve, and P10, for cell saturation density assays. In the days indicated cells were harvested using trypsin and resuspended in PBS $+5 \%$ fetal bovine serum (FBS) to inactivate the trypsin, washed, and fixed in a solution of phosphate buffer (PBS) with $3.7 \%$ of formaldehyde. All treatments and fresh medium were changed every other day. The cells were counted in Beckman Counter $\mathrm{Z2}^{\circledR}$. The graphs present the results of at least two biological replicates in which three technical replicates for each treatment were collected.

\section{Western blots}

The cells were plated in $60-\mathrm{mm}^{2}$ Corning ${ }^{\circledR}$ dishes and treated according to each experiment. The total protein was extracted and isolated in RIPA buffer (SigmaAldrich $^{\circledR}$ ) plus Halt $^{\mathrm{TM}}$ Protease Inhibitor Cocktail (Thermo Fisher ${ }^{\circ}$ ). The samples were quantified using Precision $\operatorname{Red}^{\mathrm{TM}}$ (Cytoskeleton ${ }^{\circ}$ ) and submitted to western blot. Western blots were performed by standard chemiluminescence method using SuperSignal ${ }^{\circledR}$ and Pierce ECL ${ }^{\circledR}$ (Thermo Fisher ${ }^{\circ}$ ). The images were obtained by the UVITEC $^{\circledR}$ equipment and analyzed by the Alliance ${ }^{\circledR}$ software. All the primary and secondary antibodies are listed in Supplementary Table 2.

\section{Pull down of Ras-GTP}

Raf1 RBD agarose beads were incubated with $200 \mu \mathrm{g}$ of the extract of total protein for $2 \mathrm{~h}$ at $4{ }^{\circ} \mathrm{C}$ in low rotation. Afterward, the beads attached to Ras-GTP were washed 8 times with PBS plus protease inhibitors. The beads were resuspended in $\mathrm{NuPAGE}^{\mathrm{TM}}$ sample buffer (Thermo Fisher ${ }^{\circ}$ ) and applied to the acrylamide gel (12\%). The western blot was performed using the anti-HRas antibody.

\section{Real-time PCR}

Total RNA was extracted from cell culture by RNeasy kit (Qiagen ${ }^{\circ}$ ), quantified, converted to cDNA using MultiScribe RT kit (Thermo Fisher $^{\circledR}$ ), and submitted to realtime (RT)PCR. RT-PCR was carried out using the SYBR ${ }^{\circledR}$ GREEN PCR Master Mix (Applied Biosystems ${ }^{\mathrm{TM}}$ ) combined to the primers listed in Supplementary Table 3 and the StepOne Plus PCR system. The results were calculated using the $\Delta \Delta C$ t method and then normalized by RPL19.

\section{Flow cytometry}

For the assays performed in the flow cytometer, the cells were plated in $\operatorname{Costar}^{\circledR}$ and proceeded as indicated by each experiment. All samples were run in the equipment 
Attune NxT Blue-Red (Thermo Fisher ${ }^{\circledR}$ ) collecting 30000 events in at least two biological duplicates. The raw data were treated and analyzed by FlowJo ${ }^{\circledR}$ V10.2.

\section{Cell cycle analysis}

After the indicated period and treatment, cells were harvested and fixed in ice-cold $75 \%$ ethanol overnight at $4{ }^{\circ} \mathrm{C}$. Fixed cells were washed twice in PBS, labeled with $100 \mu \mathrm{g} / \mathrm{mL}$ of propidium iodide (Thermo Fisher ${ }^{\circledR}$ ), treated with $50 \mu \mathrm{g} / \mathrm{mL}$ of RNAse A (Invitrogen ${ }^{\circledR}$ ) for $30 \mathrm{~min}$, and then immediately submitted to flow cytometry. The quantification of single-labeled cell cycle phases was obtained by Watson pragmatic method ${ }^{61}$ using FlowJo ${ }^{\circledR}$ V10.2. Cells were submitted to one hour of EdU pulse using the Click-iT ${ }^{\circledR}$ Alexa Fluor 488 (Thermo Fisher ${ }^{\circledR}$ ) according to the manufacturer's recommendations for double-labeled cell cycle analysis.

\section{Cell viability assay}

The cell viability was obtained from two methods as indicated in the experiments: sub-G1 population extracted from the cell cycle analysis and by double-labeling using Alexa Fluor ${ }^{\circledR} 488$ annexin-V/PI Dead Cell Apoptosis Kit $\left(\right.$ Thermo Fisher $\left.{ }^{\circledR}\right)$. The double-labeling was performed following the manufacturer's recommendations.

\section{Assessment of ROS levels}

The cells were plated in $\operatorname{Costar}^{\circledR}$ six-well plates. After $48 \mathrm{~h}$, the medium was replaced adding the treatments according to each experiment. The cells were incubated with $50 \mu \mathrm{M}$ of $2^{\prime}-7^{\prime}$-dichlorodihydrofluorescene diacetate (DCFDA Thermo Fisher ${ }^{\circledR}$ ) for $1 \mathrm{~h}$ to measure general oxidative species, and $10 \mu \mathrm{M}$ MitoSOX ${ }^{\mathrm{TM}}$ (Invitrogen ${ }^{\circledR}$ ) for $30 \mathrm{~min}$ to assess the levels of mitochondria superoxide. After the incubation period, the cells were harvested and analyzed by flow cytometry.

\section{Measurement of lactate levels}

The medium of 4OHT-induced and noninduced cells was collected every other day during the growth curve assessment. The media was centrifuged for $30 \mathrm{~min}$ at $14000 \mathrm{rpm}$ in Centricon microtube cutoff $10 \mathrm{KDa}$ (Vivaspin $500 \mathrm{GE} \mathrm{Healthcare}{ }^{\circledR}$ ). In total, $300 \mu \mathrm{L}$ of the sample were collected in duplicates and kept at $-80^{\circ} \mathrm{C}$ until day 10, the last day of the experiment. The lactate concentration of all samples was measured at once following the manufacturer's recommendations of the Lactate Assay Kit (Sigma-Aldrich ${ }^{\circledR}$ ). The final concentration was normalized by the number of cells per $\mathrm{cm}^{2}$ of the well from where the medium was obtained.

\section{Immunofluorescence (IF)}

For all experiments listed below, the images were captured using an Olympus BX51 fluorescence microscope coupled to a digital camera (XM10, Olympus), and were analyzed using Olympus- Cell F software (version 5.1.2640).

\section{Analysis of DNA breaks using TUNEL assay}

To evaluate the presence of DNA break and compare the keratinocyte sublineages exposed to different concentrations of $4 \mathrm{OHT}$ with their respective controls, we used terminal deoxynucleotidyl transferase-mediated dUTP-Fluorescein nick-end-labeling (TUNEL) technique using the Apoptosis Detection System, Fluorescein kit (Promega). In total, $4 \times 10^{3}$ cells $/ \mathrm{cm}^{2}$ were plated onto the coverslips. After $48 \mathrm{~h}$ of treatment, the cells were washed with PBS and fixed using $1 \%$ paraformaldehyde for $10 \mathrm{~min}$. The coverslips were washed with PBS and permeabilized by the addition of $0.1 \%$ Triton X-100 for $10 \mathrm{~min}$ at $26^{\circ} \mathrm{C}$. In all, $0.1 \mathrm{M}$ glycine was added for $5 \mathrm{~min}$ to neutralize the remaining aldehyde groups. TUNEL assay was performed according to the manufacturer's protocol. VECTASHIELD ${ }^{\circledR}$ Mounting Medium with DAPI (Vector Labs) was added to be used as an antifade mounting solution and to stain the nuclei.

\section{Analysis of replication stress by BrdU native detection assay}

For detection of long fragments of single-stranded DNA (ssDNA), a feature of replication stress, we grow keratinocytes in coverslips [induced with $50 \mathrm{nM} 4 \mathrm{OHT}$, noninduced (control), treated and nontreated with $5 \mathrm{nM} \mathrm{NAC]}$ in the presence of $50 \mathrm{mM}$ 5-bromo-2'-deoxyuridine (BrdU) for $24 \mathrm{~h}$ to allow its incorporation into DNA. After that, we washed the coverslip-containing cells using PBS and fixed them using $4 \%$ of paraformaldehyde diluted in PBS for $10 \mathrm{~min}$ at room temperature. Next, cells were washed with PBS and permeabilized with $0.2 \%$ Triton-X 100 for $10 \mathrm{~min}$ at room temperature. To ensure that all cells incorporated BrdU, replicates of each condition were subjected to DNA denaturation using $2 \mathrm{M} \mathrm{HCl}$. Then, all samples were washed, and BrdU was detected (when accessible) using $\alpha$ BrdU-rat (Abcam) for $3 \mathrm{~h}$ at room temperature, followed by a 3-h incubation with the secondary antibody Alexa Fluor 555-conjugated goat anti-rat (Thermo Scientific). After that, the coverslip-containing cells were washed using $1 \times$ PBS and deposited on slides. VECTASHIELD ${ }^{\circledR}$ Mounting Medium with DAPI (Vector Labs) was used to be an antifade mounting solution and to stain nuclear DNA.

\section{Statistical analyses}

Two-way or one-way ANOVA followed by Bonferroni multiple-comparison test was employed when appropriate as indicated in figure legends. The data are presented as mean $\pm \mathrm{SD}$. The significance is pointed as the following: ${ }^{*} P \leq 0.05$, $* * 00.01$, and ${ }^{* * * *} P \leq 0.001$. All statistical analyses and graphs were prepared using GraphPad Prism 7 software. In flow cytometry assays, 
the difference of the population distribution was calculated by the Kolmogorov-Smirnov statistic $(\mathrm{K}-\mathrm{S})$ in FlowJo ${ }^{\circledR}$ V10.2.

\section{Acknowledgements}

The text was reviewed by the Medical editing service from Rutgers Cancer Institute of new Jersey.

\section{Author details}

'Center of Toxins, Immune-response and Cell Signaling, Instituto Butantan, São Paulo, SP 05503-900, Brazil. ' ${ }^{2}$ epartment of Biochemistry, Instituto de Química, Universidade de São Paulo, São Paulo, SP 05508-000, Brazil. ${ }^{3}$ Department of Chemical and Biological Sciences, Instituto de Biociência, Universidade do Estado de São Paulo, Botucatu, SP 18618-689, Brazil. ${ }^{4}$ Department of Medicine, Washington University in St. Louis, St. Louis, MO 63110, USA. ${ }^{5}$ Department of Microbiology, Instituto de Biociências, Universidade de São Paulo, São Paulo, SP 05508-900, Brazil. ${ }^{6}$ Kogod Aging Center, Department of Anesthesiology and Perioperative Medicine, Mayo Clinic College of Medicine, Rochester, MN 55905, USA. 7 Present address: Rutgers Cancer Institute of New Jersey, New Brunswick, NJ 08901, USA

\section{Author contributions}

E.C.L. and H.A.A. conceived the study, designed the project and experiments, analyzed and interpreted the results, and wrote the paper. E.C.L. conducted most of the experiments. E.B., M.H.D., and J.D.Z. participated in the development of experimental models. M.S.S. conducted the immunofluorescence experiments. A.T.V. participated in the design of experiments related to autophagic activity assays. M.S.R. contributed to statistical analyses. All authors participated and contributed to result discussions and interpretation, and paper revision.

\section{Ethics statement}

This study was conducted with the approval of the scientific committees of Instituto de Química da Universidade de São Paulo and Instituto Butantan. All the sources of commercial kits and reagents, including commercial plasmids used, are informed in "Materials and Methods" and Supplementary Tables 1 and 2 .

\section{Funding statement}

This work was supported by the São Paulo State Foundation (Fapesp-CeTICS 2013/07467-1) and the Federal Agencies: Coordenação de Aperfeiçoamento de Pessoal de Nível Superior (CAPES) and Conselho Nacional de Desenvolvimento Científico e Tecnológico (CNPq).

\section{Conflict of interest}

The authors declare no competing interests.

\section{Publisher's note}

Springer Nature remains neutral with regard to jurisdictional claims in published maps and institutional affiliations.

Supplementary information The online version contains supplementary material available at https://doi.org/10.1038/s41419-021-03476-3.

Received: 14 October 2020 Revised: 22 January 2021 Accepted: 26 January 2021

Published online: 18 February 2021

\section{References}

1. Kawakami, E. et al. Network analyses based on comprehensive molecular interaction maps reveal robust control structures in yeast stress response pathways. npj Syst. Biol. Appl. 2, 15018 (2016).

2. Fox, E. J., Prindle, M. J. \& Loeb, L. A. Do mutator mutations fuel tumorigenesis? Cancer Metast. Rev. 32, 353-361 (2013).

3. Dias, M. H. et al. Fibroblast growth factor 2 lethally sensitizes cancer cells to stress-targeted therapeutic inhibitors. Mol. Oncol. 13, 290-306 (2019).
4. Arbyn, M. et al. Estimates of incidence and mortality of cervical cancer in 2018: a worldwide analysis. Lancet Glob. Heal 8, e191-e203 (2020).

5. Walboomers, J. M. M. et al. Human papillomavirus is a necessary cause of invasive cervical cancer worldwide. J. Pathol. 189, 12-19 (1999).

6. McCubrey, J. A. et al. Ras/Raf/MEK/ERK and PI3K/PTEN/Akt/mTOR cascade inhibitors: how mutations can result in therapy resistance and how to overcome resistance. Oncotarget 3, 1068-1111 (2012).

7. Malumbres, M. \& Barbacid, M. RAS oncogenes: the first 30 years. Nat. Rev. Cancer 3, 459-465 (2003).

8. Cox, A. D., Fesik, S. W., Kimmelman, A. C., Luo, J. \& Der, C. J. Drugging the undruggable RAS: mission possible? Nat. Rev. Drug Discov. 13, 828-851 (2014).

9. Lawrence, M. S. M. S. et al. Comprehensive genomic characterization of head and neck squamous cell carcinomas. Nature 517, 576-582 (2015).

10. Alonio, L. V. et al. Ha-ras oncogene mutation associated to progression of papillomavirus induced lesions of uterine cenvix. J. Clin. Virol. 27, 263-269 (2003).

11. Prior, I. A., Hood, F. E. \& Hartley, J. L. The frequency of Ras mutations in cancer. Cancer Res. 80, 2969-2974 (2020).

12. Fusenig, N. E. \& Boukamp, P. Multiple stages and genetic alterations in immortalization, malignant transformation, and tumor progression of human skin keratinocytes. Mol. Carcinogen. 158, 144-158 (1998).

13. Narisawa-Saito, M. et al. An in vitro multistep carcinogenesis model for human cervical cancer. Cancer Res. 68, 5699-5705 (2008).

14. Narisawa-Saito, M. et al. A critical role of MYC for transformation of human cells by HPV16 E6E7 and oncogenic HRAS. Carcinogenesis 33, 910-917 (2012).

15. Vanzo, R. et al. Autophagy role(s) in response to oncogenes and DNA replication stress. Cell Death Differ. 27, 1134-1153 (2020).

16. Mizushima, N., Levine, B., Cuervo, A. M. \& Klionsky, D. J. Autophagy fights disease through cellular self-digestion. Nature 451, 1069-1075 (2008).

17. White, E., Karp, C., Strohecker, A. M., Guo, Y. \& Mathew, R. Role of autophagy in suppression of inflammation and cancer. Curr. Opin. Cell Biol. 22, 212-217 (2010).

18. Guo, J. Y. et al. Autophagy provides metabolic substrates to maintain energy charge and nucleotide pools in Ras-driven lung cancer cells. Genes Dev. 30 1704-1717 (2016).

19. Zong, W. X., Rabinowitz, J. D. \& White, E. Mitochondria and cancer. Mol. Cell 61, 667-676 (2016).

20. Levine, B. \& Kroemer, G. Autophagy in the pathogenesis of disease. Cell 132, 27-42 (2008).

21. Shintani, T. \& Klionsky, D. J. Autophagy in health and disease: a double-edged sword. Science 306, 990-995 (2004).

22. Mathew, R. \& White, E. Autophagy in tumorigenesis and energy metabolism: friend by day, foe by night. Curr. Opin. Genet. Dev. 21, 113-119 (2011).

23. Mario, G., Martins, I. \& Kroemer, G. Autophagy in Ras-induced malignant transformation: fatal or vital? Mol. Cell 42, 1-3 (2011).

24. Ubhi, T. \& Brown, G. W. Exploiting DNA replication stress for cancer treatment. Cancer Res. 79, 1730-1739 (2019).

25. Sabatinos, S. A., Ranatunga, N. S., Yuan, J. P., Green, M. D. \& Forsburg, S. L. Replication stress in early $S$ phase generates apparent micronuclei and chromosome rearrangement in fission yeast. Mol. Biol. Cell. 26, 3439-3450 (2015).

26. Fugger, $\mathrm{K}$. et al. Human Fbh1 helicase contributes to genome maintenance via pro- and anti-recombinase activities. J. Cell Biol. 186, 655-663 (2009).

27. Mizushima, N. \& Yoshimori, T. How to interpret LC3 immunoblotting. Autophagy 3, 542-545 (2007).

28. Klionsky, D. J. et al. Guidelines for use and interpretation of assays for monitoring autophagy (3rd edition). Autophagy 12, 1-222 (2016).

29. Santana-Codina, N. et al. Oncogenic KRAS supports pancreatic cancer through regulation of nucleotide synthesis. Nat. Commun. 9, 1-13 (2018).

30. Cox, A. D. \& Der, C. J. The dark side of Ras: regulation of apoptosis. Oncogene 22, 8999-9006 (2003).

31. Karnoub, A. E. \& Weinberg, R. A. Ras oncogenes: split personalities. Nat. Rev. Mol. Cell Biol. 9, 517-531 (2008).

32. Luo, J., Solimini, N. L. \& Elledge, S. J. Principles of cancer therapy: oncogene and non-oncogene addiction. Cell 136, 823-837 (2009).

33. Gorgoulis, V. G. et al. Activation of the DNA damage checkpoint and genomic instability in human precancerous lesions. Nature 434, 907-913 (2005).

34. Seiwert, T. Y. et al. Integrative and comparative genomic analysis of HPVpositive and HPV-negative head and neck squamous cell carcinomas. Clin. Cancer Res. 21, 632-641 (2015).

35. Ang, K. K. et al. Human papillomavirus and survival of patients with oropharyngeal cancer. N. Engl. J. Med. 363, 24-35 (2010). 
36. Cleal, K. \& Baird, D. M. Catastrophic endgames: emerging mechanisms of telomere-driven genomic instability. Trends Genet. 36, 347-359 (2020).

37. Green, D. R. The coming decade of cell death research: five riddles. Cell 177, 1094-1107 (2019).

38. Gao, M. et al. Ferroptosis is an autophagic cell death process. Cell Res. 26, 1021-1032 (2016)

39. Micco, R. Di et al. Oncogene-induced senescence is a DNA damage response triggered by DNA hyper-replication. Nature 444, 638-642 (2006).

40. Maya-Mendoza, A. et al. Myc and Ras oncogenes engage different energy metabolism programs and evoke distinct patterns of oxidative and DNA replication stress. Mol. Oncol. 9, 601-616 (2015).

41. Aird, K. M. et al. Suppression of nucleotide metabolism underlies the establishment and maintenance of oncogene-induced senescence. Cell Rep. $\mathbf{3}$ 1252-1265 (2013).

42. Kotsantis, P., Petermann, E. \& Boulton, S. J. Mechanisms of oncogene-induced replication stress: jigsaw falling into place. Cancer Discov. 8, 537-555 (2018).

43. Cooke, M. S., Evans, M. D., Dizdaroglu, M. \& Lunec, J. Oxidative DNA damage: mechanisms, mutation, and disease. FASEB J. 17, 1195-1214 (2003).

44. Weinberg, F. et al. Mitochondrial metabolism and ROS generation are essential for Kras-mediated tumorigenicity. Proc. Natl Acad. Sci. USA 107, 8788-8793 (2010).

45. Green, D. R. \& Levine, B. To be or not to be? How selective autophagy and cell death govern cell fate. Cell 157, 65-75 (2014).

46. Poillet-Perez, L., Despouy, G., Delage-Mourroux, R. \& Boyer-Guittaut, M. Interplay between ROS and autophagy in cancer cells, from tumor initiation to cancer therapy. Redox Biol. 4, 184-192 (2015).

47. Youle, R. J. \& Narendra, D. P. Mechanisms of mitophagy. Nat. Rev. Mol. Cell Biol. 12, 9-14 (2011)

48. Ferro, F. et al. Autophagy and mitophagy in cancer metabolic remodelling. Semin Cell Dev. Biol. 98, 129-138 (2020).
49. Radogna, F., Dicato, M. \& Diederich, M. Cancer-type-specific crosstalk between autophagy, necroptosis and apoptosis as a pharmacological target. Biochem Pharm. 94, 1-11 (2015).

50. Mukhopadhyay, S., Panda, P. K., Sinha, N., Das, D. N. \& Bhutia, S. K. Autophagy and apoptosis: where do they meet? Apoptosis 19, 555-566 (2014).

51. White, E. Deconvoluting the context-dependent role for autophagy in cancer. Nat. Rev. Cancer 12, 401-410 (2012).

52. Rebecca, V. W. \& Amaravadi, R. K. Emerging strategies to effectively target autophagy in cancer. Oncogene 35, 1058-1065 (2015).

53. Nassour, J. et al. Autophagic cell death restricts chromosomal instability during replicative crisis. Nature 565, 659-663 (2019).

54. Doherty, J. \& Baehrecke, E. H. Life, death and autophagy. Nat. Cell Biol. 20 1110-1117 (2018)

55. Mathew, R. et al. Autophagy suppresses tumorigenesis through elimination of p62. Cell 137, 1062-1075 (2009).

56. Wang, C. et al. Elevated p62/SQS TM1 determines the fate of autophagydeficient neural stem cells by increasing superoxide. J. Cell Biol. 212, 545-560 (2016).

57. Pylayeva-Gupta, Y., Grabocka, E. \& Bar-Sagi, D. RAS oncogenes: weaving a tumorigenic web. Nat. Rev. Cancer 11, 761-774 (2011).

58. Courbet, S. et al. Replication fork movement sets chromatin loop size and origin choice in mammalian cells. Nature 455, 557-560 (2008).

59. Helt, A.-M. \& Galloway, D. A. Destabilization of the retinoblastoma tumor suppressor by human papillomavirus type $16 \mathrm{E7}$ is not sufficient to overcome cell cycle arrest in human keratinocytes. J. Virol. 75, 6737-6747 (2001).

60. Sanjana, N. E., Shalem, O. \& Zhang, F. Improved vectors and genome-wide libraries for CRISPR screening. Nat. Methods 11, 783-784 (2014).

61. Watson, J. V., Chambers, S. H. \& Smith, P. J. A pragmatic approach to the analysis of DNA histograms with a definable G1 peak. Cytometry 8, 1-8 (1987). 